\title{
TISZALÖK KORTÁRS TÁRSADALMI FOLYAMATAI
}

Szerző:

Soós Zsolt (PhD.)

Debreceni Egyetem (Magyarország)

Szerző e-mail címe:

soos.zs@ped.unideb.hu

\section{Lektorok:}

Balázs-Földi Emese (PhD.)

Debreceni Egyetem (Magyarország)

Szabó Gyula $(\mathrm{PhD})$

Debreceni Egyetem (Magyarország)

Soós Zs. (2020). Tiszalök kortárs társadalmi folyamatai. Különleges Bánásmód, 6. (2). 77-92.

DOI $10.18458 /$ KB.2020.2.77

\begin{abstract}
Absztrakt
A Tiszalökön lefolytatott kutatásunk egy hosszabb, tíz elemből álló kutatássorozat része, amelyben elsősorban az ország kedvezőtlenebb helyzetű régióiban fekvő, kisebb lakosságszámú települések főbb társadalmi jellemzőinek, aktuális társadalmi folyamatainak a feltérképezésére törekszünk. A kutatás során alapvetően a helyi lakosok nézőpontjainak a megismerése és megjelenítése a célunk. A kutatási helyszínek megválasztásában döntő szempont volt, hogy e perifériális régiók kisebb településein meglehetôsen kedvezőtlen szocio-demográfiai folyamatok zajlanak, ideértve különösen a települési lakosságszám csökkenését, az idősödést és a hátrányos helyzetû lakosság számarányának a növekedését. E folyamatok amennyiben nem történnek jelentősebb változások - még a jelenleginél is kedvezőtlenebb jövőképet vetítenek elöre. E kedvezőtlen szocio-demográfiai tendenciák egyértelmúen tetten érhetőek Tiszalökön. Ehhez kapcsolódóan a kutatás kiemelt céljának tekintettük az elvándorlásban leginkább érintett helyi fiatalság lehetőségeinek, céljainak és jövőképének, valamint a helyi közösségi kapcsolatoknak, ezen belül elsősorban a romák és a nem romák együttélési jellemzőinek megismerését.
\end{abstract}

Kulcsszavak: a fiatalok és a romák helyzete, jövőkép

Diszciplina: szociológia

\section{Abstract \\ CONTEMPORARY SOCIAL PROCESSES IN TISZALÖK}

Our research conducted in Tiszalök is a part of a longer, multiple part research series, in which we will identify the main social features and map the current social processes in the less populous settlements of the more deprived regions of the country in particular. Basically, the aim of our research is to understand and present the perspective of the local people. The decisive criterion for the selection of research sites was that the smaller settlements of these peripheral regions are subject to rather unfavorable sociodemographic processes, including in particular the decline in the population, aging, and the increase in the 
share of the disadvantaged populations. These processes - unless there are significant changes - project an even more unfavorable vision of the future. The adverse socio-demographic processes described above are definitely observable in Tiszalök. Related to this, the primary objective of the research was to understand the opportunities, goals, and vision of the local youth most affected by migration, as well as to recognize the local community relations and the characteristics of cohabitation of the Roma and non-Roma population in particular.

Keywords: the situation for young and roma people, the future vision Disciplines: sociology

\section{Kutatási módszerek és eszközök}

A kutatásban többféle módszert alkalmaztunk, egyrészt megtörtént a településre vonatkozó társadalomstatisztikai adatok (pl. népességszám alakulása, stb.) elemző összegzése, valamint a térségre és a településre vonatkozó fontosabb dokumentumok áttekintése. A kutatás fố módszerének - annak szemléletéhez igazodóan, vagyis a helybéliek nézőpontjának bemutatása érdekében - a szóbeli kikérdezést, ezen belül a részben strukturált egyéni interjút választottuk (Falus, é.n.). Előzetes feltérképezés, majd a hólabda módszer (Babbie, 1996) segítségével húsz egyéni interjút készítettünk el. Törekedtünk arra, hogy a válaszadók szociodemográfiai szempontból sokszínúek legyenek, s ezáltal a település lehető legtöbb csoportjából csatornázzunk be véleményeket.

Ebből következően a kérdezettek között voltak fiatalok, idősek, családosok, egyedülállók, roma, nem roma nemzetiséghez tartozók, foglalkozást tekintve megkérdeztünk polgármestert, pedagógusokat, közmúvelődési és szociális szakembert, közösségszervezőt, mentort, fazekast, közfoglalkoztatott segédmunkást, fogyatékossággal élő gyerme-két az otthonában gondozó (Gyermekek Otthongondozási Díjában /1993. évi III. tv. 38§/ részesüló - a továbbiakban GYOD) lakost stb.

\section{Tiszalök}

A 2018-ban 5414 lelket számláló kisváros (Net1) Szabolcs-Szatmár-Bereg megyében, a Tiszavasvári Járásban, közvetlenül Borsod-Abaúj-Zemplén megye határán fekszik. A település húszkilométeres körzetében több nagyobb, jelentősebb funkciókkal is rendelkező város található. A megyeszékhelyen kívül Hajdúnánás és Tokaj is e körbe sorolható, igaz, az utóbbiba - amennyiben a kompközlekedést nem vesszük igénybe - csak jelentős kerülővel lehet eljutni. A település meglehetősen elzárt, közúton és vasúton egyaránt nehezen megközelíthető, az idevezető közutak jelentős része rossz minőségú. A Debrecen - Tiszalök vasútvonalon napjainkban is elavult motor-kocsik („kis piros vonatok”) közlekednek, s az útvonal hosszához képest a menetidő is irreálisan hosszú.

A településhez tartozik egy napjainkban már kizárólag romák által lakott, hozzávetőlegesen 800 lélekszámú szegregátum, az Újtelep, továbbá Kisfástanya is, ahol nagyobb részben szintén hátrányos helyzetú, jelentős arányban az elmúlt években Borsod-Abaúj-Zemplén megyéből beköltözô roma családok élnek. A városhoz tartozik, ám a központi településrész közigazgatási határától mintegy öt kilométerre, a tiszalöki vízierőmú szomszédságában található az „egyéb belterület” Erőmú-lakótelep, ahol egykor jónéhány család élt, 
ám jelenleg mindössze 35 állandó lakossal rendelkezik. Ugyanakkor számos nyaraló kapott helyet a település-részen, amelyen - interjúalanyok elmondása alapján - nyaranta nyüzsgó életet élnek a részben helybéli, részben más településen lakó nyaralótulajdonosok.

A város közszolgáltatásokkal és magánszolgáltatásokkal való ellátottsága megfelel a méretének, Tiszalökön jól felszerelt általános iskola, négy tagintézménnyel rendelkező óvoda, szakgimnáziumi tagintézmény, mûvelődési ház, könyvtár, több szociális intézmény - ideértve idősek klubját, fogyatékossággal élőket segítő nappali intézményt, családok átmeneti otthonát, házi segítségnyújtást és szociális étkeztetést, család- és gyermekjóléti szolgálatot - működik.

A demográfiai folyamatokra Tiszalök esetében is érvényes az, ami a periférikus kistelepülések döntő többségében megfigyelhető Magyarországon (Bálint és Obádovics, 2018; Gödri, 2018), sőt, Európa többi fejlett országában is (EBRD, 2019), vagyis jellemző a fiatalok és részben a középkorúak elvándorlása. A lakosságszám különösen 2002-tól csökken gyorsabb ütemben. A helyi önkormányzattól kapott adatok alapján ebben az évben 6262, 2018-ban pedig csupán 5414 ember élt a városban. (Net1) A roma népesség aránya ugyanakkor növekvô ütemú, a 2011. évi népszámlálási adatok idején a lakosság mindössze 2\%-a vallotta magát a roma kisebbséghez tartozónak (KSH, 2011), ugyanakkor a megkérdezett helyiek, valamint a helyi önkormányzat a roma népesség arányát 2018ban 20-30\% közöttire becsülte. A romák aránya a fiatalok és a gyermekek között jóval magasabb, az óvodai csoportokban és az iskolai osztályokban a roma gyermekek aránya a megkérdezett pedagógusok szerint $40 \%$ körülire tehető.

\section{Tiszalök története címszavakban}

Tiszalök esetében nagy jelentôsége van annak a történelmi fejlődésvonalnak, amely már 1765-től alapvetően a városiasodás útján indította el a korábbi mezőgazdasági jellegú települést. Mintegy kétszáz évvel később, az 1971-es Országos Településhálózat-fejlesztési Koncepció e városra gyakorolt hatása megtörte a városiasodás, és a városi jellegú fejlődés folyam-atát. (Net1)

Éppen ezért - bár kutatásunkban elsősorban a jelenkori körülmények, jellemzők feltárására törekedtünk - a helyiek településsel kapcsolatos attitűdjeinek megértéséhez elengedhetet-lennek tűnik a történeti fejlődés kissé távolabbra nyúló bemutatása.

„Tiszalök 1765-ben Mária Teréziától kapott vásártartási jogot, ezzel a környék ipari és kereskedelmi centrumává vált. A jogot az uralkodó adományozta kiváltságlevelek alakjában. [...] A helypénzszedés jogát a vásártartás jogával együtt, vagy külön is lehetett engedélyezni. Tiszalöknek az adománylevél a vásártar-tási joggal együtt a helypénzszedés jogát is adományozta $[\ldots]$ A vásártartási jog egyben mező-városi rangot is jelentett. $[\ldots]$

Vásártartási és mezővárosi jogával a környező jobbágyközségek központjává vált.” (Net2) Mindez a társadalmi életre, az itt élók társadalmi státuszára is hatást gyakorolt, 1772-ben, a városról (TiszaLeök) szóló földesúri urbáriumban kiemelik, hogy ez évben már csupán 41 jobbágybirtok volt a településen, a lakosság többsége pedig „szabadmenetelư", vagyis nem röghöz kötött jobbágy volt. Tiszalök e központi funkciója később tovább erősödött, 1870-tól a járásközpont mellett tíz falvat magába foglaló Dadai-alsójárás székhelye lett. „A kiegyezés után az út- és vasútépítkezések, a Tiszát szabályozó föld-munkák, a gátépítések jó kereseti lehetőséget biztosítottak a lakosságnak.

Harminc év alatt 1869-1900 között ezer fővel nőtt a település lakóinak száma." (Net2) Az elérhető adatok szerint a XX. század fordulóján már 4477 éltek Tiszalökön, azaz közel annyian, mint napjainkban, majd 120 évvel később. 
A település már a XIX. században erôteljes városi jegyeket mutatott, 1847-től gyógyszertára, 1867-től postája, 1882-tôl önálló orvosa, 1884-tôl takarékpénztára, 1894-től távíró berendezése, 1896-tól vasútállomása volt, de múködött helyben szolgabíróság, járásbíróság és börtön is. Az 1900-as évek elején Szabolcsi Tiszavidék címmel már hetilapja is volt. „Járási székhely voltának köszönhetően itt volt a legtöbb értelmiségi. A gyermekek beiskolázása is a legjobb a járásban. A huszadik század fordulóján a lakosság 64\%-a már tudott írni-olvasni." (Net2)

Bár 1950 január 1-től megszűnt a Dadai-alsójárás, Tiszalök helyzete ekkor még közigazgatásilag gyakorlatilag nem változott, ugyanis a község (hiszen maga a mezőváros közigazgatási kategória megszűnt a XX. században) megmaradt az ekkortól kialakított, s egészen 1971-ig fenntartott Tiszalöki járás székhelyé-nek. Ezen időszak gazdaságitársadalmi fejlődését jól mutatja a vízierőmú beruházás megvalósulása, a település első - azóta már megszúnt - gimnáziumának az 1953. évi megnyitása. A központi egészségügyi, oktatási, közigazgatási funkciók, az elérhető álláslehetőségek továbbra is vonzóak voltak, így a lakosságszám e húsz éve alatt mintegy 1500 fövel, 6630ra emelke-dett 1970-re, amely azonban - egy rövid stagnálási idôszakot követően - azóta folyamatosan csökken. (Net1). A csökkenés egyik alapvető oka az 1971. évtől érvénybe lépő Országos Településhálózat-fejlesztési Koncepció (Andorka 1997), melynek eredménye-képpen Tiszalök járási székhelyszerepe megszúnt, azóta a város a Tiszavasvári járás (közben egy időszakban Tiszavasvári kistérség) egyik településeként múködik.

\section{Tiszalök elmúlt évtizedei - ahogy a helyiek látják}

Az 1971. évi döntés a helybéliek szerint is jelentős változást, törést hozott a település életében.
Emellett a rendszerváltást, majd a XXI. század kezdetétől datálható időszakot tekintik a város mindennapjaiban fordulópontoknak.

Az egyik, 1939-ben született interjúalany (nyugdíjas nô) - aki az 1953-ban megnyitott helyi gimnázium első osztályának tanulója volt, később pedig pénzügyesként dolgozott a településen elmondása alapján az '50-es években: „Nehéz volt itt az élet, kürqdeni kellett a napi megélhetésért [...] édesapám földmíves volt, åt akarta, bogy otthon dolgozzak, kiváltképpen, mert édesanyám nagyon beteges volt, de én tanulni akartam, és tanultam is. Persze iskola mellett sokat dolgoztunk."

A politikai életben megvalósuló elnyomó jelleg, a fegyelmezettség, a funkcionalitás a mindennapokat is jellemezte, különösen a gimnazisták életében. „Egyenrubában kellett járni a városban is, meg mi, gimnazisták, nem mehettünk bálba sem, mert hogy nézne az ki, nagyon nagy szigorúság volt a gimnáziumban. Mindenbez. engedély kellett, de sokszor aẓt sem kaptuk meg." (80 éves nő, nyugdijas)

Az '50-es évekre a gazdasági fejlődés ellenére sem gondolnak vissza szívesen a kérdezett helyiek. Ezen időszakról, illetve az ebben az időszakban épült vízlépcsôről és vízierőműroôl - ellentétben kutatássorozatunk előző helyszínével, a vízierőmúrendszer másik elemének otthont adó Kiskörével, ahol valamennyi interjúalany a település életét meghatározó üzemként jellemezte az erőművet - kevés szó esett. Ennek több oka lehet. Az egyik objektív ok, hogy az ipari jellegú városnak csupán az egyik, s még csak nem is a legnagyobb foglalkoztatója volt az erőmú. A másik, hogy a vízlépcsőt elsősorban az itteni munkatáborba deportált, zömében orosz hadifogságból hazatelepített sváb emberek építették. A későbbi munkákban is nagyobb részben helyi, vagy környékbeli emberek vettek részt, így az építkezés - ellentétben Kiskörével - nem eredményezett jelentős horderejú társadalmi változásokat. Sôt, interjúalanyaink egy része azt emelte ki ennek kapcsán, hogy itt a munkások helyiek, meg 
környékbeliek voltak, de vezetőket máshonnan hozták, mert „Senki nem lehet próféta a saját bazájában.” (80 éves nő, nyugdíjas)

A későbbi évtizedekre viszont inkább pozitívan gondolt vissza interjúalany (80 éves nő, nyugdíjas), kiemelve, hogy számos üzem - fürészüzem, pékség, a HÓDIKÖT varróüzeme, stb. - múködött és adott megélhetést az embereknek, egy részük a '80-as évekig, más részük egészen a rendszerváltás idôszakáig. Ezt, és azt, hogy sokkal inkább jellemző volt a helyi közösségi élet, hogy voltak presszók, „kocsmakörök”, ahol az adott korcsmakörbe tartozó fiatalok sokat beszélgethettek, voltak bálok, múködött mozi, jellemző volt nyaranta, hogy a fiatalok, de akár a középkorúak összejöttek a holt Tisza (holtág) partján, gyakorlatilag minden kérdezett idôsebb, vagy legalább középkorú interjúalany megemlítette. Szintén nyugdíjaskorú, de jelenleg is praktizáló háziorvos interjúalany (70 éves nő) - aki Békés megyéből a vízierőmúben állást kapott férjével költözött Tiszalökre - úgy emlékszik, hogy a '70-es évek végéig nyüzsgő, és aktív volt a tiszalöki élet. A ’71-es területrendezési koncepció hatása az évtized végére azonban már egyértelmúen érződött: „Olyan langyossá vált itt az élet, különösen az értelmiségieknek [...] nem nagyon maradt itt megfeleló állás a diplomásoknak, nem nagyon maradt jövökép. A családtól is art hallhatta a fiatal: "Na gyermekem, nadrágos ember lettél, eredj el nagyvárosba rendes állást keresni magadnak." [...] Én 1974-ben költöztem ide, azóta ezerrel kevesebben vagyunk."

A rendszerváltozás időszakának kezdetét a kérdezett lakosok nagyobb része pozitívan élte meg, $\mathrm{s}$ az elsô években még beruházások is történtek, pl. külföldi befektető vette át a helyi varrodát. Ugyanakkor ezzel egyidejűleg számos munkalehetôség szűnt meg helyben és a környező településeken egyaránt, különösen a férfiak kerültek nagyobb számban az utcára. „A férfiak munkanélküliek lettek, mikëö̧ben a nök maradtak családfenntartók, meg rájuk bárult a bázimunka, a gyermeknevelés [...]
Ez a generáció lelkileg és testileg is nagyon elhasználódott, a nôk a sok teherbe, a férfiak meg a munkanélkiuliségbe. [...] Aztán sokan, föleg a fiatalok elkö̈ltöztek, ahogy mondtam, ezerrel kevesebben vagyunk, de az sem mindegy, kik maradnak. Itt az elöregedés az egyik. legnagyobb gond, az egyik legnagyobb teher. Ezek a testileg és lelkileg elhasználódott idösek egyre nagyobb terbet jelentenek a családoknak is, de az ellatórendszernek is." (70 éves nő, háziorvos)

Az itt gyermekeskedő, fiatalságát a településen töltő '30-as és '40-es éveiben járó generációk megkérdezett tagjai, akiket ezen időszakban a foglalkoztatási problémák áttételesen, szüleiken keresztül érintettek, alapvetően pozitívan gondolnak vissza gyermek-korukra és ifjúkori éveikre. Ennek elsődleges okának azt tartják, hogy minden fontos intézmény, szolgáltatás elérhető volt helyben, aktív és intenzív volt a kulturális és a közösségi élet.

Úgy vélik, ebben döntô változás a 2000-es évektől, különösen annak a második felétől történt, amikortól még kevesebb munkalehetôség maradt helyben és a környéken, s bezárt valamennyi kulturált szórakozási lehetőséget nyújtó presszó, $\mathrm{s}$ amikortól az emberek egyre kevésbé igényelték/igénylik a közösségi rendezvényeket, egymás társaságát. Ennek valamennyi kérdezett a fó okait a romló anyagi lehetóségekben, a kulturált szórakozási lehetôségek hiányában, valamint abban látja, hogy a technológiai fejlődéssel a technikai eszközök, az okostelefonok, a közösségi oldalak azok, amelyekkel a fiatalok mellett, a középkorúak is legszívesebben töltik az idejüket. „A kü̈tyük átvették az irányitást az emberek élete felett. Régen mi eljártunk biciklizni, le a boltághor, a családdal is, a barátokekal is [...] ma ilyenekere már alig van igény, leginkább csake a géperésre." (39 éves nő, fazekas, múzeumpedagógus)

„A közösségi élet már nincs olyan magas szinten, mint tinédzser koromban volt. [...] Mindenki a saját gondjával van elfoglalva és nem foglalkoznak a közösségi élettel. $A$ z emberek bele vannak fásulva abba, hogy napról - napra 
élnek. Emiatt nincs igény arra, hogy közösségi életet éljenek. A gyerekek, fiatalok is föleg interneteznek, gépeznek, tévét néznek, amikor bazaérnek. A szülök pedig nem tesznek ennek ellenében semmit, mert könnyebb hagyni, mint tenni ellene.” (36 éves nő, banki ügyintéző)

„Régebben nagyobb összetartás volt, nagyobb közösségi élet, mert nem voltak ekekora különbségek anyagiakban, jobban össze is jártak az, emberek [...] Most a családosok. mind otthon vannak hétvégén, akinek van pénze megteheti, hogy elmegy kirándulni, de egyébként mindenki saját magával foglalkozik. [...] Tiszavasváriba járnak el a fiatalok, mert ott vannak kulturáltabb sqórakozási lehetöségek." (46 éves nő, óvodapedagógus)

\section{A tiszalöki lelki állapot}

Látható tehát, hogy a már évszázadokkal ezelőtt városiasodó, a '70-es évekig járásközponti funkciót betöltő település fejlődése a '70-es évek tudatos központi döntésének következtében megtorpant, sőt, elindult egyfajta visszafejlődési, lecsúszási folyamat. Ennek a megtapasztalása, generációkon való áthagyományozódása jelentősen befolyásolja a helybéliek világlátását, általános hangulatát. Ezt a negatív hangulatot, világlátást erősítette, hogy az elmúlt évtizedekben - eltekintve az elmúlt években Borsodból beköltöző, zömében hátrányosabb helyzetű roma családoktól - kevéssé költöztek más településekről Tiszalökre.

Az ideköltözők, vagy itt munkát vállalók jelentős része pedig valamely posztra kinevezett vezető volt. Ez egyrészt azt eredményezte, hogy a megkérdezettek egy része úgy véli, hátrányba kerültek saját településükön a "messziról jött idegenekkel szemben”, nem kaptak, kapnak elég megbecsülést. Másrészt e tényezők is okozhatják, hogy a helyiek jelentős része „bezárkózott”, „csak magával és a családjával töródik", és alapvetően bizalmatlan az idegenekkel, de a más csoportba tartozó helyiekkel szemben is, ami tetten érhető a romák - nem romák közötti viszonyban. A helyiek lelki állapota kapcsán leg- gyakrabban elhangzott jelzők közé az: elkeseredettség, érdektelenség, nemtörődömség, elégedetlenség, indulatosság, zárkózottság, bizalmatlanság sorolható. „Amikor idejöttem tanitani Tiszavasváriból az akkori igazgató megkeresésére, hivására, eleinte a belyiek bizalmatlanok voltak, neheren fogadnak be idegeneket [...] de késóbb, ha látják, hogy az ember jól teszi a dolgát, elfogadják, barátságossá vállnak. [...] Nagyok az indulatok a helyiekben az önkormányzat irányában." (50 éves férfi, középiskolai pedagógus, nem helybéli). „A tiszalöki, az egy nagyon kritikus népség. Semmi sem jó az embereknek, mindenben találnak kivetnivalót.” (53 éves nő, közművelődési szakember). „Itt a semmi sem jó mentalitás jellem₹ô." (26 éves férfi, közfoglalkoztatott). „Az ember itt polgármesterként megtanulja, hogy semmi sem jó. Lehet itt bármit csinálni." (56 éves férfi, polgármester). „A belyiek nagyon bizalmatlanok, elóször a bizalmat kell elnyerni, ami nem egyszerü." (30 éves nő, közösségfejlesztô)

Mindezt erősíti, hogy ellentétben előző vizsgálati helyszínnel, Kiskörével, ahol egyidejűleg érkeztek, telepedtek le jelentős számban „idegenek” a vízierőmú építésekor, s ahol nem jellemző ez az elzárkózás, bizalmatlanság, Tiszalökön gyakorlatilag valamennyi interjúalany kiemelte, hogy ő törzsgyökeres helybéli, vagy éppen ennek az ellenkezőjét, vagyis kulcsfontosságúnak tekintik e jellemzőt. Már a legelső interjúalany (53 éves nő, közművelődési szakember) is azzal kezdte - igaz, viccelődve, ujjaival beszéd közben idézőjelet rajzolva a levegőbe - hogy „Én nem vagyok ám egy "gyütt-ment«." E kifejezés számos további interjúban elhangzott. Ez a jellemző - külső szemlélóként nézve - úgy tűnik, jelentôsen nehezíti a mindennapi életet, a helyiek együttélését.

\section{A fiatalok helyzetérö1}

Egységes tiszalöki fiatalságról nem beszélhetünk, a családi háttér itt ugyanúgy jelentősen befolyásolja a helyi fiatalok tanulmányi előmenetelét és későbbi 
életlehetőségeit, mint az ország más területein. (Lannert, 2018) A megkérdezett hét, 30 év alatti interjúalany mindegyike meglehetősen negatívan nyilatkozott a településról. „Tiszalökról konkrétan az. égvilágon semmi pozitivumot nem tudok mondani." (23 éves férfi, egyetemi hallgató) Ennek ellenére öten helyben képzelik el a jövőjüket, igaz, ezt két válaszadó egyfajta kényszerhelyzetnek tekinti. Mindenesetre az interjúk későbbi részeiben mégiscsak több erősséget, előnyt is megemlíttettek, ami némiképp szintén alátámasztja a negatív lelki állapotot, az "itt semmi sem jó" mentalitást.

\section{Tiszalök gyengeségei - miért nem vonzó a} település a fiataloknak

1) A település, és az egész régió elszigeteltsége, visszafejlódése.,NNem városiasodik tovább a település, inkább visszafejlódik [...] Messze van az autópálya is, de ez. az, egész régió el van szigetelódve, túlmutat a probléma a helyi viszonyokon." (46 éves nő, óvodapedagógus); „Itt minden csak visszafejlódik, bezár, elmegy, az üzremek, a presszók, a gimnázium sem gimnázium már, pedig jobb lenne.” (58 éves nő, rokkantnyugdíjas) „A gimnázium átalakitása szerintem nagy érvágás volt a városnak, azóta érezhetöen kisebb az, igény a kulturális programokra." (53 éves nő, közművelődési szakember)

2) A munkalehetőségek, különösen a minőségi munkalehetőségek hiánya helyben és a környéken. „Itt nem nagyon vannak álláslehetöségek, ha vannak is, inkább alsókategóriás állások. (25 éves nő, könyvelő) "Szeretek itt dolgozni, de közmunkában ötvenezerét [...] ebböl nem lehet kijönni [...] de amikor az. Algidában dolgoztam néhány éve Nyíregyen, rengeteg plusżmunkával, meg majd megfagyott az ember, akekor is hazavittem 84 ezret [...] Pesten, de pláne külföldön nem ennyit keresnek." (26 éves férfi, közmunkás) „Itt már be vannak telve azoke az állások, amiket diplomások tudnának betölteni. Inkább a szakmával rendelkeęóknek, firikai, meg gyári munkára van lebetöség itt, meg a körmyéken." (34 éves nő, szociális szakember)

3) A kulturált szórakozási lehetőségek, egyáltalán a szórakozási lehetőségek hiánya. „Itt semmi nincs, nincs hová elmenni. Nincs egy vendéglátóhely a Tiszaparton, meg sehol [...] péntek, meg szombat esténként ez. egy üres, kihalt város. (27 éves férfi, mérnök) „A fiatalok Tiszavasváriba, Nyíregyházára járnak el szórakozni, itt nem is müködik semmi. (46 éves nō, óvodapedagógus) „Ez. egy kihalt város hétvégén.” (25 éves nő, könyvelő)

4) A kistelepülési környezetből adódóan ismerik, és „ki is beszélik egymást” a helyiek.,„Ez egy kis hely, itt mindenki ismer mindenkit, meg ki is beszélik az embert. Aki ę̧t nem birja, annak ez nyilván nem is jo." (20 éves nő, tanuló)

5) A megkérdezettek, különösen a fiatalok jelentôs része említette meg hátrányként az iskolai oktatás, különösen a középiskolai oktatás elégtelen színvonalát. „Az oktatás színvonala, az nagyon gyér. $\mathrm{Ez}$ biányzilk a városból. Látom azöösémen, aki 11 éves. Régen azért nem volt ennyire ross\%: [...] Egy csomóan elviszile innen a gyerekeket a szomszéd falu általános iskolájába Szorgalmatosra, ott egyáltalán nincsenek romák. (27 éves férfi, mérnök); „A belyi középiskola nagyon gyenge, oda csak az ilyen kettes tanulók mennek." (25 éves nö, könyveló); ,A Telekibe járok, régen is oda jártam [...] régen is nagyon rossz. volt, de most még rosszabb. Régen is csak heten voltunk az osztályban nem cigányok. Szinte csak cigányok járnak [...] Nekem, bogy apu egyedül nevel, meg itt van a kishúgom, nincs más válas:tásom, nem mehettem el innen." (20 éves nő, tanuló)

6) A közintézményben, a helyi polgármesteri hivatalban dolgozók nem kellő szaktudása, érdektelensége, nemtörödömsége. „Nem lehet mindent a forrásbiányra fogni. Itt az igazi szakemberek biányoznak. Mindenki elvan, elüldögél csak a bivatalban, meg a belyén, és ezeeket az embereket igazából nem érdekli semmi. Nem törö́dnek semmivel, nem csinálnak semmit [...] Olyan már 
itt az élet, hogy ha nem lennének itt a szüleim, az öcsém, be nem tenném ide a lában." (27 éves férfi, mérnök); „Ez̨eknek az embereknek (értelmező közbevetés: az Újtelepen élő romáknak) úgy kellene megtanitani mindent, mint a gyerekeknek. A kisebbségi önkormányzatnak, meg a családsegitönek lenne ez a dolga, de nem csinálják. Ide a romákhoz senki ki nem jár, senki ki nem teszi ide a lábát.” (41 éves roma nő, GYOD-ban részesül); „Nagyok az indulatok a belyiekben az önkormányzat irányában. [...] Hogy nem igazán történnek érdemi dolgok, fejlesztések." (50 éves férfi, középiskolai pedagógus)

7) A roma lakosság növekvő részaránya. A megkérdezettek döntő többsége a település gyengeségeként, mégpedig az itteni „normális életet egyre inkább ellebetetlenitö" (27 éves férfi, mérnök) gyengeségeként emelte ki a roma lakosság részaránynövekedését. Sőt, a megkérdezett 30 év alatti hét fiatal közül hatan ezt említették először a település gyengeségének. Mindez a roma - nem roma együttélés tekintetében meghatározó információ.

\section{A település erősségei, megtartó erejének el- emei}

1) Gyönyörű természeti környezet, maga a Tisza, a tiszai holtág, a településszéli arborétum. Mindez önmagában, a helyieknek is nagy érték, ugyanakkor a turizmus fejlesztésének is kedvező alapot adhatna.

2) A kisváros nyugalma, ellentétben a nagyvárosokkal Tiszalök nem zajos, a levegő nem szennyezett, az élet nem annyira „,rohanós”. „Itt meg tud állni az ember beszélgetni, nem az a rohanás van, mint ami Debrecenben volt, amikor ott éltem [...] Soba senkinek se volt semmire ideje.” (30 éves nő, közösségfejlesztő)

3) Helyben élnek a családtagok, rokonok, barátok, ismerősök. Van kivel beszélgetni, nem magányosak az emberek, s van kire számítani. „Debrecenben mi volt [...] hazamentem a munkából, ültem magamban a szobában, nem volt kihez szólni. Magányos ott az. ember. [...] Itt ez. nem így van, itt a családom, itt lehet másokkeal találkozni, beszélni." (30 éves nő, közösségfejlesztö); „Az egyik ok, hogy itt telepszünk le, bogy itt a családunk, oda is fogunk költözni elösqör, a sqülökhör. [...] tudunk kire sqámitani." (23 éves férfi, egyetemista) „Nekem itt volt a családom, Édesapám már kialakitotta a mühelyt. Nekem itt van kialakitva az életem, itt tudom gyakorolni a szakmám, nagyrészt a családomnak köszönhetöen.” (39 éves nő, fazekas, múzeumpedagógus)

4) Közintézményekkel, szolgáltatásokkal való ellátottság. „Itt minden van, ami egy családnak kell. Vannak boltok, helyben vannak az iskolák, meg szak.körök a gyerekeknek, meg a müvbázban is vannak programok, zumba, meg ilyenek." (30 éves nő, közösségfejlesztő) „Jó, hogy belyben lebet iskolába járni, még ha nem is olyan színvonalú, de nem kell elmenni innen, még középiskolába sem." (20 éves nő, tanuló)

5) A településen olcsók az ingatlanok, így lehetőség adódik az életkezdésre. A párom is itt dolgozik az. iskolában, meg jövöre már én is pedagógus leszek. Teszem azt elmennénk Debrecenbe, fizetnénk az albérletet, semmit sem tudnánk félretenni [...] Az teljességgel esélytelen ebben a szakmában, hogy valaki Debrecenben vegyen egy lakást [...] itt a családunk, oda is fogunk költözni elöször a sqülökhöz: Ott tudunk spórolni is, meg itt néhány millióból lehet egy kertesházat venni. Meglehet alapozni egy családi életet. (23 éves férfi, egyetemi hallgató); „Itt egy családi ház, még felujitással együtt is megvan nyolc, nagyon maximum 10 millióból, ami Debrecenben legalább 35-40 millió lenne." (30 éves nő, közösségfejlesztô)

6) A helyi iskolában döntő többségében vannak a hátrányos, illetve halmozottan hátrányos helyzetű gyermekek, ezáltan kedvezőbb az intézmény finanszírozása, s magasabb a pedagógusok bére. „Debrecenben mindketten az alapbért vinnénk haza. Itt, hogy sok a HH-s, meg a 3H-s gyerek, jobb a finanszirozás, a pótlékekal jobban lehet keresni, ami nem mellékes egy családalapitáshoz:" (23 éves férfi, egyetemi hallgató)

7) A közmunkaprogramok biztosítása a rosszabb helyzetű lakosságnak. „Ami jó például, hogy itt van a 
közmunka. Nem csak nekem, hanem másoknak is. Itt a közintézményekben rengeteg közmunkás van.” (26 éves férfi, közmunkás); „A település elönye a közmunkaprogram. Jó az embereknek is, hogy nem otthon ülnek segélyen, meg jó az intézményeknek is, hogy van segitség [...] Na persze ott a másik oldal, hogy ebböl nemigen lehet normálisan megélni. Meg lassan, kis túlzással, de lassan annyi közmunkás van az óvodában, mint gyerek, és mindig jönnének még többen.” (46 éves nö, óvodapedagógus)

8) Lokálpatriotizmus, a településhez való lelki kötődés. A lokálpatriotizmust a kérdezettek többsége emelte ki erősségként, igaz, az idősebbek egy része úgy véli, a fiatalokra ez már nem, vagy csak kis számban jellemzô. „Nem is tudnék máshol élni, amikor ma is lemegyek a holt Tiszához, még a könnyem is mindig kicsordul." (39 éves nő, fazekas, múzeumpedagógus); "Igen, azt mondtam, hogy itt az égvilágon semmi pozitivum nincs, ez igaz. És mégis valahogy idehúr a szivïnk. Ezt nem lehet megmagyarázni." (23 éves férfi, egyetemi hallgató).

A település inkább a kevésbé képzett, rosszabb helyzetû fiataloknak ad tanulási, akár szakmatanulási, majd pedig elsősorban fizikai munkakörökben, illetve közmunkában elhelyezkedési, és szerény megélhetési lehetôséget. A motiváltabb, aktívabb, képzettebb fiatalok nagyobb része, azok, akiknek erre van lehetőségük, máshol keresik a boldogulást. Ennek egyik oka a helyi lehetőségek (munka, szórakozás stb.) szűkös volta, a másik ok viszont a településen tapasztalható elkeseredettség, kilátástalanság, esetenként talán ehhez is kapcsolódóan az érdektelenség, a közömbösség, a nemtörődömség. A település e tekintetben bizonyos mértékben anómiás állapotokat tükröz.

\section{Roma - nem roma együttélés}

A roma - nem roma együttélés tekintetében az interjúkban elhangzottak mellett, sokatmondóak a romák helyzetével kapcsolatos alábbi jellemzők:
- A romák lakóhelye a városban, vagyis annak feltárása, hogy a roma lakosság a településen a többségi társadalomba integrálódottan, vagy éppen szegregáltan él-e.

- A roma - nem roma vegyes házasságok száma.

- A roma származású emberek közintézményekben, szellemi munkakörben való foglalkoztatása.

1) A romák lakóhelye a városban: a helybéli roma lakosság kis része, azok, akik jobb helyzetűek - a helyiek szerint összességében csupán néhány család - a város központi részén él. A döntő többség azonban a város központi kerületétől távolabb eső Újtelep kizárólag romák lakta szegregátumában, illetve a szintén szegregátumnak tekinthető Kisfástanyán él. Mindkét településrész tipikus leromló állapotú szegregátum, amelyek egyfajta „világvége közeli” hangulatot sugallnak. E helyek állapotáról, megítéléséről sokat mondó adat, hogy e településrészeken néhány százezer forintért is lehet lakható állapotú házat venni. Részben emiatt is jellemző az a folyamat, hogy a Családok Otthonteremtési Támogatásának (17/2016. (II. 10.) Korm. rendelet) segítségével, nagyobb számban költöztek Tiszalök-Kisfástanyára Borsod-Abaúj-Zemplén megyéből hátrányosabb helyzetű roma családok. E területi elkülönüléshez, s a nem romáknak a roma lakossághoz való viszonyához kapcsolódó tény az is, hogy Újtelep kizárólag roma gyerekeket ellátó egyébként az '50-es éveket idéző állapotú (pl. fával, cserépkályhában fütenek) - tagóvodájában évek óta nem tudják betölteni az üres óvodapedagógusi munkakört, így évek óta egyetlen, a nyugdíjaskorhoz közelítő óvodapedagógus látja el e feladatot.

2) A roma - nem roma vegyes házasságok:: a településen kevéssé jellemzőek a roma - nem roma vegyes házasságok, interjúalanyaink nem, vagy alig tudnak ilyenről. „Nébány ilyen család van, de örájuk jellemző, hogy ök nagyon stabilak. Nagyon rendezetten 
élnek, bent a városban. Rendesen nevelik a gyereküket. Ugyanúgy élnek, mint a magyar családok." (34 éves nő, szociális szakember)

3) A roma származááu emberek közintéz-ményekben, szuellemi munkakörben való foglalkoztatása. A település szinte valamennyi közintézményét felkeresve nem találkoztunk roma származású, szellemi munkakörben dolgozó emberrel. A helyieket kérdezve nem tudtak ilyen interjúalanyt javasolni nekünk. Igaz, voltak olyanok, akik kikerülték e kérést, mondván, nem szabad nyilvántartani, hogy ki az, aki roma származású, így erről nem szívesen beszélnének. Volt, aki pedig így nyilatkozott: „Ez nem jellemzó, az itteni romák nem nagyon tanulnak tovább, nem szereznek olyan végzettséget, ami kellene egy ilyen állás betöltéséhez:” (54 éves nő, óvodapedagógus).

Egyetlen interjúalany (34 éves nő, szociális szakember) említette meg, hogy abban a fogyatékossággal élőket segítő intézményben, ahol ő maga is dolgozik, van egy roma származású, jelenleg GYED-en lévő munkatárs, s hogy tudomása szerint korábban a család- és gyermekjóléti szolgálatnál is dolgozott egy roma származású segítő. (A helyi család- és gyermekjóléti szolgálat elzárkózott a kutatásban való részvételtől).

A korábbiakban kifejtett folyamatok, különösen a zárkózottság, bizalmatlanság, a helyi romák szegregálódása, s ebből következően az előítéletesség talán átlagosnál erősebb - egyébiránt kölcsönösnek tünő - jelenléte, s a régebbről fennmaradt megítélések és viszonyulások a romák és a nem romák együttélésére is döntő hatást gyakorolnak. (Szociálpszichológiai vizsgálatok (Forgas, 2007) egyértelmúen bizonyítják, hogy a szegregált környezetből, a más kultúrák megismerésének hiányából szinte magától értetődően következik az, hogy az adott közösség tagjai félnek az ismeretlentől, éppen ezért bizalmatlanok is. Ezen érzelmek, s a helyzet kezelése - tudni illik az, hogy valamiféle tudásra mégiscsak szükségem van arról a másik közösségről, akinek tagjaival azért időnként mégiscsak találkozom - nagy valószínűséggel túláltalánosításon alapuló előítéletes gondolkodást eredményezhet.)

A korábbi évtizedekben a romák és a nem romák között meglévő egyenlőtlen helyi társadalmi megítélést konzerváló látásmódot talán az alábbi mondat fejezi ki leginkább: „A legtöbb roma az Újtelepen lakik, illetve a sorompó túlesö részén [...] Sok család jön az anyaotthonba, akik csak egy évig maradnak a településen. Ök rontják a város képét. A belyi romák már tudják, hogy mit szabad nekik és mit nem, mig a betelepedett kisebbség úgy gondolja, hogy mindent megtehet.” (39 nő, fazekas, múzeumpedagógus). Emellett több helybéli is megemlítette, hogy: a (törzsgyökeres) ,cigányok tudják, hol a belyük a közösségben”. Jól érzékelhető, hogy a helyi nem romák egy része szerint sem térben, sem társadalmi helyzetben nem ugyanott, mint a nem romáké. E mondatok, és az interjúk jelentős részében e témával kapcsolatosan megfogalmazott vélemények, valamint a romák helyzetére vonatkozó fenti tények egyaránt a cigányság másfajta kezelését, hátrányosabb helyzetét valószínúsítik. Mindez egyben a településen a romák és a nem romák közötti feszültebb viszonyt eredményez, még akkor is, ha több interjúalany is megjegyezte, hogy a romák és a nem romák között itt kevesebb, és kevésbé erőteljes, durva atrocitások vannak, mint az e tekintettben hírhedté vált, s emiatt az országos médiába is gyakran bekerült Tiszavasváriban.

A megkérdezett fiatalok és a pedagógusok többsége, valamint egyik roma származású interjúalany egyaránt kiemelte, hogy a romák és a nem romák közötti konfliktusok egyre gyakoribbá válnak. E tekintetben az oktatási intézményekben, különösen a középiskolában kedvezőtlen, és egyre romló a helyzet.

„Ezek a kis óvodások bekerülnek ide, és eleinte nagyon sok gond van. A roma anyukák le se tesqik a gyereket, amig csecsemö, de aztán kicsapják az udvarra, azt csinál, amit akar [...] és nagyon temperamentumosak, nem tanulták. meg, hogy alkalmarkodjanak, igy eleinte megvan a 
baj [...] Nagyon igénylik a szeretet, s nagyon tudnak szeretni is, és ha érzik, hogy szeretike öket, akkor mindent megtesznek azért, aki szereti öket. Igazán nagy öröm itt óvónéninek lenni, annyi szeretetet kap az ember." (54 éves nő, óvodapedagógus - szegregált tagóvoda) „Itt az óvodában értékközvetités folyike, és sikeres is, mig megvan a közeli kapcsolat, a kontroll [...] de ahogy ebböl kikerü̈nek, otthon mást látnak, és eqeek az értékek késóbb, ahogy egyre nagyobbak, el is tünnek [...] Valahogy felnött korban is meg kellene lenni ennek a szoros kapcsolatnak, a sұülökekel is törödni kellene valakinek." (46 éves nő, óvodapedagógus) „Én nagyon jóban vagyok a roma gyerekekekel is, mondhatom, barátok is vagyunk [...] de ahogy nönek, tinédzserek lesz̨nek, változnak, másképp kezdenek el viselkedni, másképp néznek az emberre, akkor már nem tudunk barátok lenni." (46 éves férfi, pedagógus)

A megkérdezett hét 30 év alatti fiatalból hatan említették, hogy az általános iskolában, de kiváltképpen a helyi középiskolában, ahol már döntô többségében vannak a roma származású diákok, rengeteg atrocitás, „vegzálás”, fizikai bántalmazás éri a nem roma származásúakat, éppen származásuk miatt. Részben emiatt egyre gyakoribb, hogy nem roma származású diákokat átvisznek más iskolába, illetve egyre gyakoribb a helyi pedagógusok iskola, vagy pályaelhagyása is.

„Rengeteg sok cigány van, és nem úgy viselkednek az emberrel, mint kéne [...] Nem szeretik a magyarokat, látják, kibe lehet belekötni, és abba bele is kötnek, és azt már sosem hagyják békén [...] Sokan elmentek emiatt, meg tanárok is sokan elmentek ezele miatt." (20 éves nó, tanuló)

Bár a diákság körében jelennek meg leinkább a nyílt konfliktusok, a megkérdezettek egy része szerint a felnőttek körében is romlik a helyzet. „Mondok egy példát, sok ismerösöm mondja, hogyha látja, hogy a vonaton csak cigányok vannak egy kocsiban, tízen, tizenketten, inkább nem squáll fel, inkább elkerüli a bajt." (27 éves férfi, mérnök)
A témával kapcsolatos kiemelendő információ még, hogy a megkérdezettek jelentős része szerint a roma - nem roma konfliktusoknál nagyobb számú, és durvább konfliktusok vannak jelen a roma lakosság között, az iskoláskorú gyermekek és a felnőttek között egyaránt. „Több konfliktus, meg verekedés inkább a romák között van itt az iskolában is [...] Például a telepi, meg a városi romák közöott." (53 éves nő, pedagógus) A település centrum részén, korábban vegyes házasságban élő, kétgyermekes roma származású interjúalany (41 éves nő, GYOD-ban részesül) is megemlítette, hogy elsősorban a romák között, különösen a városi és a telepi romák között vannak konfliktusok. „Én nem szeretem öket (értelmező közbevetés: a telepi romákat), mert nem így élnek, abogy kell [...] Azt a példát adják át a gyerekeknek, hogy szüljenek 13 évesen, és nem azt, hogy tanuljanak. Pedig a tanulásban van a jövô" [...] Egyból akarnak mindent, és ba nem úgy sikerül, nincs bennük kitartás [...] Amikor megjön a péñ, akekor zsanna-manna van, aztán meg nincs mit enni, ątán meg mennek a kamatos pénzért [...] Ök sem szereretnek engem, mert nagy a szám, megmondom az igazat [...] de az itteni embereket (értelmező közbevetés: városi nem romákat) sžeretem, meg ök is szeretnek engem."

A korábbiakban ismertetett információk alapján kirajzolódó folyamatnak többféle értelmezése lehet. A szociálpszichológiai, szociális munka és szociálpedagógiai ismeretekre építve úgy túnik, az egyik alapprobléma, hogy bár a hátrányos helyzetû roma szülők szeretik gyermekeiket, ragaszkodnak hozzájuk (,A roma anyukák le se teszik a gyereket, amig csecsemố[...]"), ám nincsennek birtokában sok olyan ismeretnek, képességnek, amelyek szükségesek lennének a felnővő gyermekeik megfelelő neveléséhez (Thirsch, in Sárkány, 2011), s ebben kevéssé kapnak adekvát segítséget. (,Valabogy felnött korban is meg kellene lenni ennek a szoros kapcsolatnak, a szülókkel is törödni kellene valakinek.”; „Ezeknek az embereknek úgy kellene megtanitani mindent, mint a gyerekeknek. A kisebbségi önkormányzatnak, meg a családsegitönek. lenne 
ez. a dolga, de nem csinálják, ide a romákhoz senki ki nem jár, senki ki nem tesæi ide a lábát.”) E probléma átmenetileg megoldódik akkor, amikor a kisgyerek bekerül az óvodába, s ott egy elfogadó, őt szeretô óvodapedagógus kezd el vele foglalkozni. Az óvodai viszonyok nagy előnye e tekintetben, hogy a mindennapok még szabadabb mederben folynak, ami jobban igazodik a roma gyermekek mindennapjaihoz, s még kevésbé jelenik meg a kötöttség és a teljesítményelv. E viszonyok a közoktatásban, különösen a felső tagozatban jelentősen változnak. Eltúnik a diákok és pedagógusok közötti fizikai kontaktus, előtérbe kerül a teljesítményelv, a teljesítmény alapján való jutalmazás, s háttérbe szorul „az önmagáért való elfogadás.” A mindennapok pedig egyre erőteljesebben szabályozottak. (Somlai, 1997) Mindeközben a roma gyermekek ismeretei is bővülnek. Egyre több információt szereznek a körülöttük lévő világról, szembesülnek térbeli kirekesztett helyzetükkel, a „városi-telepi” elkülönüléssel, ezáltal az „ők” és „mi” kategóriákkal, a nem romákhoz, illetve általában a városközpontban élőkhöz képest rosszabb anyagi lehetőségeikkel. Az iskolai követelményeknek való megfelelés gyakori sikertelensége, az egyenlőtlenséggel, a kirekesztettséggel való szembesülés jelentős frusztrációt eredményez. (Forgas, 2007) A frusztrációból eredő düh az általában valamivel jobb helyzetû nem roma, vagy akár városközponti roma fiatalokra irányul. Mindez tovább mélyíti e csoportok között a meglévő szakadékot. E jelenség a helyi jellemzők és folyamatok tükrében érthető, ugyanakkor természe-tesen nem elfogadható, s nem jelenti azt sem, hogy a bántalmazott, vagy „vegzált" gyermekeknek, fiataloknak ez ne lenne szörnyú tapasztalat, s azt sem, hogy ne kellene tenni ez ellen.

A fentiekből egy másik jelenség is kirajzolódik. Úgy tûnik, ahhoz, hogy a romák helyzete javuljon, a nem roma lakosság elfogadja őket, némiképp cigányságukról is le kell mondaniuk. Teljesen úgy kell élniük, ahogy az a nem romák körében elvárt. Ezzel azonban szembe kerülnek a „telepi roma” lakossággal. Mindezt jól példázzák roma interjúalany (41 éves nő, GYOD-ban részesül) mondatai. Ugyanakkor a korábban felsorolt jellemzők, illetve az a megközelítés, hogy a helyi romák „tudják, hol a helyük" arra utal, hogy az elfogadás nem feltétlenül jelent befogadást is. S bár a felnőtt lakosság körében már kevesebb a konfliktus, hiszen tudják, hogy példának okáért megélhetésük a közmunkától függ, az abba való bekerülésükrôl pedig a helyi nem roma vezetók döntenek, s persze megtanulták azt is, hogy az agresszív tetteknek akár büntetőjogi következménye lehet, a mélyben lappangó indulatok, feszültségek jól érzékelhetőek, s változtatás nélkül a jövőben súlyosabb következményekkel járhatnak. (E kérdéskör kapcsán fontos információ, hogy ellentétben Kiskörével, a megkérdezett tiszalöki romák meglehetősen bizalmatlanok voltak velünk, s két kivétellel elzárkóztak az interjúadástól.)

\section{A problémakezelés: a fizikai életfeltételek javítására való törekvés}

1) A városban kialakítottak egy a szakgimnáziumhoz kapcsolódó modern tanmúhelyt, melyet eredményesen használnak az iskola hallgatói.

2)Kialakítottak egy ipari parkot a településen. Ugyanakkor a polgármester elmondása szerint: „Nebéz befeketetóket csábitani a településre.” Ennek egyik valószínúsíthető oka, ahogy azt többen is kiemelték, hogy Tiszalök ipari szempontból nem rendelkezik kedvező adottságokkal, nehéz megközelíteni, kevés helyben a megfelelő képzettséggel rendelkező szakember. Ugyanakkor megfogalmazódott olyan vélemény is, hogy a hivatali dolgozók sem szakértelemmel, sem motivációval nem rendelkeznek feladataik ellátásához, ami - a tényleges toborzómunka hiánya miatt - szintén hozzájárulhat az ipari park kihasználatlanságához. 
3)Elindult a város központi részeinek átalakítása, ennek keretében egy új kávéház felépítése. Bár e tekintetben is számos negatív vélemény hangzott el, különösen amiatt, hogy a változtatás következtében sok fát kivágtak, sokan pozitívan nyilatkoztak az átalakításról, arról, hogy végre van valamiféle megújulás a városban. A kávéház, amennyiben ténylegesen múködni is fog, ahogy az interjúkból kiderült, valós helyi igények kielégítését szolgálhatja.

4) A településen kialakítottak egy természetvédelmi látogató központot, a Bagolyvárat, amit egy civil szervezet múködtett. Ugyanakkor több interjúalany is kiemelte, hogy ténylegesen kevéssé mûködik a hely, sajnálatosan nem szerveznek ott programokat sem gyermekeknek, sem családoknak, sem felnőtteknek.

5) A természeti adottságokra építve a tiszai holtág körül elkészült több faépület, melyek pihenő és kilátóhelyként funkcionálnak, $\mathrm{s}$ az eredeti tervek szerint az egyikben büfé is múködött volna. Emellett az egyes szigetszerū részekre átvezető fahíd és fasétányrendszert is kialakítottak. Ugyanakkor azt a problémát, hogy nem múködik itt egy büfé, ahol meg lehetne inni egy kávét, lehetne venni egy üdítôt, vagy szendvicset - bár az épületkialakítások erre lehetôséget adnak - ez a fejlesztés végül nem oldotta meg. Talán ennél is nagyobb problémának tűnik, hogy a közelmúltban átadott épületeknek, sétányrendszernek láthatóan nincs gondos gazdája. A vízben, illetve vízparton álló faszerkezetek időtállóságát biztosító kezelése nem történt meg, így ezen új szerkezetek már korhadásnak indultak. Amenynyiben ebben nem történik változás, a jelentős költségú beruházás néhány éven belül az enyészet áldozatává válik. Mindez megerősíti azt, hogy egyfajta elkeseredettség, kilátástalanság, ebből fakadó érdektelenség és nemtörődömség jellemzi a települést.
A lakosság segítése, különös tekintettel a hátrányos helyzetű családokra - „Ki lesz az a kisbíró, aki ezt végre tudja hajtani?”

Egykori doktori képzésem meghatározó oktatója volt Ferge Zsuzsa professzor, aki számos alkalommal kiemelte, hogy a múltban és a jelenben is sok jószándékú kezdeményezés, jogszabályi kötelezettség bukott meg azon, hogy „Nem volt olyan kisbiró, aki eat végre tudta volna hajtani." Gyakran fejeződött be úgy egy-egy a szociális ágazatra vonatkozó pozitív szándékú jogszabály elemzése, hogy professzorasszony egy sóhaj kíséretében megjegyezte, hogy: „De honnan lesz annyi kisbiró, aki ezt végre tudná hajtani?” A szociális alapszolgáltatásokban végzett többévi munkám, két évtizednyi kutatói tapasztalatom, s e tiszalöki kutatás is arra világított rá, hogy a jószándékú, elöre mutató kezdeményezések nagyon gyakran buknak el amiatt, hogy az egyes programok végrehajtói nem rendelkeznek kellő szaktudással, és/vagy kellő motivációval a programok megvalósítására. Így e programoknak gyakran a tényleges elsődleges funkciója - az eredeti elsődleges cél (pl. hátrányos helyzetû romák felzárkóztatásának segítése) helyett - az lesz, hogy az abban alkalmazottaknak munkahelyet és munkajövedelmet biztosítsanak.

\section{Felzárkóztató, közösségerősítő és men- torprogram Tiszalökön}

E tekintetben - a múvelődési ház képzési és szabadidôs programjain kívül - alapvetően egy korábbi, s két jelenlegi fejlesztő jellegû projektről számoltak be a megkérdezettek. A jelenlegi programok fö-, illetve félállásban alkalmazott felelőseivel lehetôségünk adódott interjút készíteni. A polgármester, a helyi vezetés koncepciója szerint, a különböző felzárkóztató programokban való részvétel lehetôségét ki kell használnia a településeknek. Egyrészt amiatt, mert e programok álláslehetőséget biztosítanak a helybélieknek, ami fontos feladata a települési önkormányzatoknak. 
Másrészt pedig e célok fontosága miatt. A polgármester (56 éves férfi) ez irányú elkötelezettségét jól jelezték mondatai, s a mondanivalóját kísérô hiteles gesztusai is. „Az a legegyszerübb, ba legyintünk a cigányságra, ez sokak bozzáállása [...] de nincs olyan gyerek, aki reménytelen.” Ezt a fajta attitűdöt ugyanakkor kevéssé lehetett érzékelni a program fiatal alkalmazottain.

\section{Szociális rehabilitációs program, a szegregá- tumban élő roma lakosság helyzetének a javí- tása}

Az Európai Unió által finanszírozott program keretében közösségi ház épült a szegregátumban, és éveken keresztül kilenc embert alkalmaztak fóállásban annak érdekében, hogy segítsék a roma lakosság helyzetének javulását, jólétének növekedését.

Interjúalanyok ezzel kapcsolatban azt emelték ki, hogy ezen időszakban volt néhány program, például közös fơzés, annak megtanítása, hogyan lehet olcsón ételeket készíteni. Illetve néhány olyan program, amikor ismert embereket, köztük ismert roma embereket, pl. Oláh Gergőt meghívták, aki beszélt a helyiekkel, s aki igazi példakép lehet a helyi roma gyerekeknek. Ugyanakkor a legtöbben ennek kapcsán kiemelték, hogy a lehetőségekhez képest nagyon kevés dolog történt, a projekt alkalmazottai leginkább „A lábukat lógatták, meg gépeztete naphoszszat." (41 éves roma nő, GYOD-ban részesül) A helyi szinten jelentôs méretűnek tekinthetô projekt érezhetó javulást a cigányság körében a megkérdezettek szerint nem eredményezett. Ráadásul napjainkban a közösségi ház - annak ellenére, hogy fó, illetve félállású munkatársakkal közösségfejlesztésiés mentorprojekt múködik a településen - teljesen kihasználatlanul áll.

\section{Közösségfejlesztési- és mentorprojekt}

A közösségfejlesztési projekt 30 éves főállású munkatársa andragógus és humánerőforrás menedzser, míg a mentorprojekt négyórában foglalkozta- tott, emellett a helyi hivatalban fóállásban pályázati referensként dolgozó 25 éves munkatársa agrártudományi képzettséggel rendelkezik. A közösségfejlesztési projektben kirándulások, tóparti rendezvények, beszélgetések, valamint egy ifjúsági klub létrehozásának tervén keresztül, elsősorban a fiatalságot próbálták megszólítani, eddig viszonylag kisebb sikerrel. E projektelem keretében emellett elsősorban a középosztályt megcélzó tréningeket, ezen belül önismereti, lelki egészség megőrzését célzó és konfliktuskezelési tréninget szerveztek. A hátrányosabb helyzetú lakosság kevéssé kapcsolódik be e programelemekbe. A mentorálási program keretében a hivatalban biztosítanak az azt igénylők részére pályaválasztási tanácsadást, valamint szerveztek munkaerőpiaci börzét is. Bár a programban elsôdlegesen a halmozottan hátrányos helyzetúek segitése lenne a cél, ténylegesen kevéssé érik el ezeket az embereket. A mentor (25 éves nó) szerint ennek az elsődleges oka ezen emberek motiválatlansága: „Van, aki nem is akarja [...] Meg van olyan, aki igazából dolgozni sem akar [...] Én mindig azt mondom, aki dolgozni akar, az tud is dolgozni.”; „A környéken elég sok obyan hely van, abol el tudnának belyezkedni, a Jabilban, a Legóban." (30 éves nó, közösségfejlesztô)

Mindemellett kiemelendő, hogy a mentorprogramról való tájékoztatás úgy zajlott, hogy a közfoglalkoztatottakat alkalmazó ,[...] kht-hoz kimentünk, hogy hivják össze az embereket, hogy van ilyen lehetöség." (25 éves nő, mentor). A szegregátumban lévő közösségi házat nem használják e célokra, s nem történik megkeresés sem a mentor (25 éves nő) részéről, akinek elmondása szerint a mentorálási programelemnek nem része a helyiek mentorálásba való bevonásának motiválása. „Azért az megvan adva, hogy milyen programokat csináljunk, olyan programlehetöség nincs, aminek a célja, hogy a mentorálásba bevonjuk az embereket, ilyet csak öneróból lebetne." E mondatok segítői szemszögből is - önmagukért beszélnek. E mondatokat kisérő gesztusok, szarkasztikus 
megjegyzések (pl. a segítés során alkalmazható helyi erőforrásokra, általában a segítési lehetőségek, és az ezzel kapcsolatos nehézségek és veszélyek feltárására irányuló kérdés kapcsán gúnyos összenézés mellett elhangzó mondat: „Ezeket a tréningen is nagyon szerettiik." /25 éves nő, mentor/) is megerôsítették a programmal, az abba bevonandó hátrányos helyzetűekkel kapcsolatos, alapvetően negatívnak tűnő attitűdöt. Mindez azért megjegyzendő, hogy rámutasson arra is, hogy egy ilyen programhoz kapcsolt rövid, tréningszerú képzés aligha alkalmas a segítségnyújtáshoz szükséges attitűd és szakmai tudás kialakításához.

Kiemelendő, hogy nem célunk „pellengérre állítani” a program alkalmazottait, ugyanakkor fontos felhívni a figyelmet arra, hogy egy segitői program sikerességéhez elengedhetetlen, hogy az abban részt vevők kelló szociális szakmai ismeretekkel, tudással, és mindenekelőtt segítői attitűddel rendelkezzenek. A legalább három és fél évig tartó felsőfokú szociális képzések adekvát ismeretközvetítése, gyakorlatai éppen e tudások, képességek és szemlélet kialakítását és megerôsítését célozzák. Az elfogadó (a kliens feltétel nélküli elfogadása) és empatikus szemlélet (Rogers, 2019), az ítélkezés helyett a megértés, motiválás és önbizalomadás stb. képessége elengedhetetlen, s önmagában még nem is elegendő feltétele az eredményes szociális munkának. Ezen jelentős összegeket felemésztő, azonban eredményeket gyakran kevéssé felmutatni képes programok alapvető hibája rendszerint a kelló szociális szaktudással, megfelelő segítői képességekkel és attitüddel rendelkező szakemberek hiánya. Ennek megváltozásához viszont arra is szükség lenne, hogy ne legyen érvényes az a széles körben jelenlévő vélemény, hogy a segitői munka végzéséhez nem szükséges különösebb tudás, különösebb képesség, elegendő elvégezni egy rövid, az adott projekthez kapcsolódó tanfolyamot, vagy tréninget a kellő eredményességú beavatkozáshoz. E programokra költött, országos szinten óriási összegek gyakran ablakon kidobott pénznek túnnek, s az eredménytelenség - mivel azt a szociális segítéssel azonosítják akkor is, ha benne gyakran nem szakemberek „tevékenykednek” - csak tovább rontja a segítői szakma amúgy is kedvezőtlen megítélését.

\section{Támogató}

A tanulmány elkészítéséhez szükséges kutatómunka az EFOP-3.4.3-16-2016-00021 „A Debreceni Egyetem fejlesztése a felsőfokú oktatás minőségének és hozzáférhetőségének együttes javítása érdekében" címú projekt támogatásával valósult meg.

\section{Irodalom}

Andorka, R. (1996): Szociológiai. Budapest: Osiris.

Bálint, L., Obádovics, C. (2018): Belföldi vándorlás. In Monostori Judit, Öri Péter, Spéder Zsolt (szerk.): Demográfiai portré 2018. Jelentés a magyar népesség helyzetéröl. Budapest: KSH Népességtudományi Kutatóintézet. 217-236.

Babbie, E. (1996): A társadalomtudományi kutatás gyakorlata. Budapest: Balassi Kiadó.

Europien Bank for Recontruction end Development (EBRD) (2019): Transicion Report 2019-20.

https://www.ebrd.com/transition-report-2019-20 (Letöltés: 2019.12.10.)

Falus, I. (szerk.) (é.n.): Bevezetés a pedagógiai kutatás módszereibe. Budapest: Műszaki Könyvkiadó Kft,

Forgas, J. P. (2007): A társas érintkeezés pszichológiája. Budapest: Kairos.

Gödri, I. (2018): Nemzetközi vándorlás. In Monostori Judit, Öri Péter, Spéder Zsolt (szerk.): Demográfiai portré 2018. Jelentés a magyar népesség belyzetéról. Budapest: KSH Népességtudományi Kutatóintézet. 237-270.

Lannert, J.(2018): Nem gyermeknek való vidék. A magyar oktatás és a 21. századi kihívások. In Kolosi, T., Tóth István, Gy. (Szerk.): Társadalmi Riport 2018. Budapest: TÁRKI, 167-185. 
Rogers, C. R. (2019): Valakivé válni - A személyiség sqületése. Budapest: EDGE $2000 \mathrm{Kft}$.

Sárkány, P. (2011): Szociálpedagógiai elméletek. Paidea könyvek. Budapest: Jel kiadó.

Somlai, P. (1997): Szocializáció. Budapest: Corvina.

Internetes források

Net1: Kisköre város Önkormányzatának Polgármesteri Hivatala: Kisköre demográfiai adatai. Kisköre, 2018. http://www.tiszalok.hu/ documents/tiszalok-demografiai-adatai/ (Letöltés: 2019.12.10.)

Net2: http://www.tiszalok.hu/tiszaloktortenelme (Letöltés: 2019.12.10.)
Felhasznált jogszabályok

1993. évi III. tv. a szociális igazgatásról és szociális ellátásokról

17/2016. (II. 10.) Korm. rendelet a használt lakás vásárlásához, bővítéséhez igényelhető családi otthonteremtési kedvezményről

\section{Felhasznát dokumentumfilm}

Biczó, G., Szabó, H. (2019): Kisvilágok 2, dokumentumfilm-sorozat: Tiszalök. 67. 